18. Al-Yaari M. Paraffin Wax Deposition: Mitigation and Removal Techniques. SPE Saudi Arabia Section Young Professionals Technical Symposium. 2011. doi: http://doi.org/10.2118/155412-ms

19. Gupta A., Sircar A. Introduction to Pigging \& a Case Study on Pigging of an Onshore Crude Oil Trunkline. 2016. URL https://www.researchgate.net/publication/307583466_Introduction to Pigging a Case Study on Pigging of an Onshore Crude_oil_Trunkline Last accessed: 16.03 .2018

20. Skorobagach M. A. Problemy ekspluatatsii sistemy sbora gaza na mestorozhdenii Medvezh'e // Tekhnologii nefti i gaza. 2011. Issue 6. P. $42-47$

21. Bratakh M. I., Skrylnyk K. Yu., Burova M. Ya. Syntez zadachi transportuvannia bahatofazovykh seredovyshch truboprovidnoiu systemoiu // Intehrovani tekhnolohii promyslovosti. Intehrovani tekhnolohii ta enerhozberezhennia. 2013. Issue 4. P. 38-45.

22. Bratakh M., Romanova V. 2 - Phase and multiphase flows handling in gathering system. St. Andrews, 2017. P. 131-136.

23. Lemmon E. W., Huber M. L., McLinden M. O. NIST Standard Reference Database 23 Reference Fluid Thermodynamic and Transport Properties-REFPROP, Version 9.1. Standard Reference Data Program. Gaithersburg, 2013. URL: https://www.nist.gov/ publications/nist-standard-reference-database-23-reference-fluidthermodynamic-and-transport

24. Hughmark G. A. Holdup in Gas Liquid Flow // Chemical Engineering Progress. 1962. Issue 58. P. 62-65.
25. Panic D. Challenging Conventional Erosional Velocity Limitations for High Rate Gas Wells // CEED Seminar Proceedings. Chevron Australia Pty Ltd, 2009

26. American Petroleum Institute. Recommended Practice for Design and Installation of Offshore Production Platform Piping Systems. API RP 14E, Washington DC

Gorin Petro, Postgraduate Student, Department of Construction of Oil and Gas Pipelines and Gas Storage Tanks, Ivano-Frankivsk National Technical University of Oil and Gas, Ukraine, ORCID http://orcid.org/0000-0001-6312-5255,e-mail:petrogorin@gmail.com

Tymkiv Dmytro, Doctor of Technical Sciences, Professor, Head of the Department of Software, Ivano-Frankivsk National Technical University of Oil and Gas, Ukraine, ORCID: http://orcid.org/00000001-6054-143X, e-mail: informatik@nung.edu.ua

Bratakh Mikhailo, PhD, Division for the Collection, Preparation and Transport of Hydrocarbons of the Department of Ground Infrastructure, JSC UkrGasVydobuvannya, Kyiv, Ukraine, ORCID: http:// orcid.org/0000-0002-5464-7921,e-mail: mikhailo_bratakh@ukr.net

Filipchuk Oleksandr, Division for the Collection, Preparation and Transport of Hydrocarbons of the Department of Ground Infrastructure, JSC UkrGasVydobuvannya, Kyiv, Ukraine, ORCID: http://orcid.org/ 0000-0003-4255-1663,e-mail:oleksandr.filipchuk@outlook.com

\section{Lysyy A.,} Kotenko V., Yakovtsev $\mathbf{S}$.

\title{
RATIONALIZATION OF PORT INFRASTRUCTURE MANAGEMENT DURING ICE NAVIGATION
}

Об’єктом дослідження є управління морською портовою інфраструктурою в період льодової навігації. Одним з найбільш проблемних питань є раціоналізація і ефективність льодової проводки. На основі статистичних даних було відзначено значне зниження вантажообігу в портах Азовського моря (Маріуполь i Бердянськ (Україна)) протягом усього льодового періоду. Проведено дослідження необхідності використання аналізу і прогнозування сезонних процесів в управлінні виробничою діяльністю морських портів, за допомогою статистичних даних, для визначення динаміки вантажообігу морських портів в період льодової обстановки. На основі статистичного аналізу даних було сформульовано поняття сезонності льодоутворення в Азовському морі.

В прочесі дослідження дано визначення поняття фактора сезонності як категоріі, що виражається у вигляді коливальних прощесів. А також розроблено підхід до формування інформаційної бази, що враховує різні форми виробничої діяльності порту в умовах льодової обстановки, що задовольняє вимогам безперервного планування і регулювання роботи порту. Запропонований і розроблений словесний алгоритм прогнозу стану льодового покриву для формування караванів з метою статистичного прогнозування, включаючи всі стадї обробки динамічних рядів. В результаті було доведено суттєве зменшення вантажообігу портів в період льодової обстановки і запропоновані способи підвищення пропускної здатності водних шляхів в льодовий період. На думку авторів, за допомогою фактора сезонності і прогнозування льодоутворення, на основі словесного алгоритму, можна досягти зменшення витрат на використання криголама під час льодової навігації. Передбачається, що зниження виходів криголама в рейс може бути знижено з $10-15$ до 4-5. Це, в свою чергу, значно знизить витрати портів на утримання криголама і підвищить продуктивність портів під час льодової навігащії.

Ключові слова: управління морською портовою інфраструктурою, збільшення вантажообігу, морський порт, льодова навігащія.

\section{Introduction}

The management, organization and planning of yearround sea transportation largely depends on the influence of external factors, in particular on the conditions of the winter period of navigation. Rational management of the port infrastructure contributes to increasing the turnover of goods regardless of seasonal fluctuations. Under the port infrastructure refers to the set of available means of communication, transport terminals and vehicles that 
perform transportation or ensure their implementation. One of the components of the port infrastructure is icebreakers. All over the world there is an acute problem of maintaining cargo flows in the ice period. In general, during the ice period, the global cargo traffic decreases by more than 5 times compared with the summer-autumn navigation period, which negatively affects the performance of the ports. The wiring of ships along main canals in ice conditions is characterized not only by the limited width of the free passage of a convoy of ships, but also by the high level of environmental and environmental variability. In such difficult conditions, the process of managing shipping is complicated by the application of the relevant regulatory documents on ship escort modes and requires prompt response to external factors. Studies of navigation conditions during the ice season show that methods and calculations that take into account both the natural and production aspects of the transport process, which have a significant impact on the management and planning of port operations, are relevant.

\section{The object of research and its technological audit}

The object of research is the management of the sea port infrastructure during the ice navigation period.

Port infrastructure management during ice navigation is always associated with additional difficulties and risks for the ship, cargo and crew. Additional risks and costs are not conducive to attracting ship-owners to ports, since the lack of specific deadlines for handling ships significantly complicates the further scheduled travel of a particular ship. Following in the convoy or without it requires the navigators to be prepared for unforeseen situations, to assess the capabilities and condition of the ship, the hydrometeorological conditions, the condition and characteristics of the ice.

Cargo transportation is an integral part of managing the flow of goods and includes two interrelated processes:

1) production (directly the process of transportation);

2) appeal (commercial and financial operation of ships).

These processes are united by the law of the market, according to which the financial efficiency of transportation by sea is determined by the value of the freight rate for transportation minus the total cost of transport services.

The production process involves three basic elements: human labor, objects of labor (transported: cargo and/or passengers) and means of labor (ships). At the same time, the cost of cargo increases depending on the assessment of the cost of seafarers' labor and operating costs.

An incorrect assessment of the situation and the lack of qualified management of individual elements of the port infrastructure can cause damage to the hull of the ship or chaining it in the ice. This, in turn, may carry a threat to the ship and crew, as well as cause additional costs associated with delaying the ship, polluting the environment, late delivery of the cargo or damage to it.

Rationalization of the port infrastructure management during the ice navigation period is connected with the need to improve the safety of navigation and requires solving the problems of optimizing the elements of the transport process and increasing the accuracy of determining the ship's position. As well as the crew's ability to operate successfully in various sailing conditions. All these and other aspects of shipping require a systematic approach using the deduction method when solving an important transportation problem - sea transportation during the ice period.

\section{The aim and objectives of research}

The aim of research is studying the problem of increasing cargo turnover and improving the quality of freight traffic during the ice navigation period by rationalizing the management of the sea port infrastructure.

To achieve this aim, the following objectives are set:

1. To define the concept of «seasonality factor».

2. To develop an approach to the formation of information base that takes into account various forms of the port's production activities in ice-cold conditions that satisfy the requirements of continuous planning and regulation of the port operation.

3. To develop a verbal algorithm for predicting the state of ice cover for the formation of convoys for the purpose of statistical forecasting, including all stages of processing time series.

\section{Research of existing solutions of the problem}

The study of world ports data shows a significant decrease in cargo turnover during the ice period [1]. The decline in cargo turnover during the winter period is associated with the carrying capacity of the sea routes due to the constant freezing of shallow seas and the idleness of ships in anticipation of icebreaking. There is a very high percentage of hull damage as a result of movements and ice compressions [2]. Based on the work, a high level of accident rate of ships during the ice period is revealed, which is caused by navigational errors and is $38.7 \%$. This, in turn, indicates an incorrect assessment by the crew of the capabilities of ships in ice conditions. Severe climatic conditions and the ice thickness, sometimes reaching up to one and a half meters, at least leads to a ship's idle time. This entails additional costs for ship-owners and the reluctance of them to operate the ship in such severe conditions, and may also lead to catastrophic environmental pollution and human casualties.

A priority strategy for the development of ports in the context of globalization has been to increase the competitiveness of maritime transport through the effective management of auxiliary fleet. One of the problems of managing the efficient operation of ports during the year is the lack of ice-breakers and ice-class ships, which leads to waiting and idle ships. This problem is solved by solving the algorithm of rhythmic, continuous posting of ship convoys under the posting of two icebreakers. The construction of a multipurpose ship for ice pilotage of ships with a higher standard of strength, a powerful engine and improved maneuverability, according to experts, should solve the problem [3].

In [4], the problems of navigation and accidents during the ice period in the Baltic Sea are considered in detail. However, specific proposals to reduce the risks of ice navigation are not proposed.

In [5], important issues of navigation with an icebreaker are touched upon, but the method of improving safety is not fully disclosed. The authors of [6] carry out 
a significant analysis of the ice cover of the Sea of Azov, although the issue of systematizing data to improve the safety of navigation in this area remains open. Partially, the question of seasonality is considered in [7]. However, the question of its influence on the ports of the Sea of Azov and navigation is not disclosed. Studies [8] are devoted to the issue of port performance, but the work of the port during ice conditions is not considered.

The authors of [9] show the importance and the need to improve the efficiency of ice convoying. However, the question of the influence of system analysis of seasonality is not considered. The authors of [10] emphasize the importance and need for an effective use of an icebreaker in the Sea of Azov, but no specific analysis of the ice situation has been carried out.

The need to solve the problem in a shorter time, as well as the financial and time costs of the proposed ideas, encouraged the authors to in-depth analysis of the situation, as well as to develop a rational algorithm that can solve this problem. To compile the algorithm, data from the existing experience of ice pilotage of ship convoys are used, as well as data on the state of the ice cover and the timing of the onset of ice phenomena. The proposed idea can be used to plan ice operations and stabilize cargo traffic during the ice period, as well as to ensure navigation safety during the formation of ship convoy.

\section{Methods of research}

To solve the objectives and achieve the aim, the following methods are used in the work:

- theoretical generalization - in the study of the information base of the studied issue;

- statistical analysis - when studying the dynamics of cargo turnover;

- graphic method - for visual presentation of information;

- mathematical method - for carrying out calculations and data analysis;

- system approach - with a comprehensive study of ice navigation capacity.

\section{Research results}

The external natural environment determines the navigation features of navigation, which greatly affect the regularity of the port's cargo turnover and the technical and operational characteristics of vehicles used in a particular navigation area. Proper planning of the upcoming transition in the ice, taking into account and analyzing all the factors, contributes to the leveling of undue risks, damage to the ship and cargo delay.

Let's consider and analyze the effects of ice navigation on changes in cargo turnover using the example of Mariupol and Berdiansk ports (Ukraine), based on data from cargo turnover during the ice campaign (January - March) and the next three months, starting in 2014 (Table 1). According to the presented data, it is noted that in the port of Mariupol in 2014 the decline in cargo turnover was approxima- tely $33 \%$ (1.332 thousand tons), and in the port of Berdiansk decreased by $17 \%$ (73 thousand tons). From 2015 to March, in Mariupol, from January to March, there was a decrease in freight turnover by $43 \%$ (2035 thousand tons), and in Berdiansk - by $18 \%$ (85 thousand tons). In 2016, a decrease in Mariupol was $6 \%$ (129 thousand tons), in Berdiansk - $27 \%$ (338 thousand tons). During 2017, during the ice situation, the turnover of Mariupol fell by $39 \%$ (773 thousand tons), and in Berdiansk $51 \%$ (552 thousand tons). In 2018, the decline was $40 \%$ (807 thousand tons) in Mariupol and $60 \%$ (457 thousand tons) in Berdiansk (Table 1).

Table 1

Dynamics of cargo turnover in the period of ice and non-ice navigation in the period 2014-2018

\begin{tabular}{|c|c|c|c|c|c|}
\hline \multirow{2}{*}{ Period } & \multirow{2}{*}{ Port } & \multirow{2}{*}{$\begin{array}{c}\text { Ice period } \\
\text { (January } \\
\end{array}$} & March) & \multirow{2}{*}{$\begin{array}{c}\text { Non-ice time } \\
\text { (April - } \\
\text { June) }\end{array}$} & \multicolumn{2}{|c|}{$\begin{array}{c}\text { Reduced freight } \\
\text { turnover }\end{array}$} \\
\cline { 5 - 6 } 2014 & thousand tons & $\%$ \\
\cline { 5 - 6 } & Mariupol & 2725.8 & 4058 & 1332 & 33 \\
\hline \multirow{2}{*}{2015} & Berdiansk & 370 & 443.2 & 73.2 & 17 \\
\cline { 2 - 6 } & Mariupol & 2647 & 4683 & 2036 & 43 \\
\hline \multirow{2}{*}{2016} & Berdiansk & 398.7 & 484 & 85.3 & 18 \\
\cline { 2 - 6 } & Mariupol & 2185 & 2315 & 130 & 6 \\
\hline \multirow{2}{*}{2017} & Berdiansk & 909.9 & 1248.8 & 338.9 & 2 \\
\cline { 2 - 6 } & Mariupol & 1204.27 & 1977.92 & 773.65 & 39 \\
\hline \multirow{2}{*}{2018} & Berdiansk & 530.2 & 1082.1 & 551.9 & 51 \\
\cline { 2 - 6 } & Mariupol & 1207.27 & 2014.57 & 807.3 & 40 \\
\hline
\end{tabular}

Note: compiled by the authors based on the data [1]

Let's consider the definition of the type, size and nature of the interaction of ice-class ships (Table 2) in the nonarctic southern seas. In the process of convoying ships, the ice convoy interacts with broken ice in the channel behind the icebreaker, colliding with individual ice floes; in the process of splitting ice and posting a convoy, the icebreaker must effectively overcome ice fields of varying intensity [11].

Table 2

Ice classes of ships of the largest classification communities

\begin{tabular}{|l|c|c|c|c|c|}
\hline \multicolumn{1}{|c|}{ Classification Society } & \multicolumn{5}{|c|}{ Ice class } \\
\hline Finnish-Swedish Ice Class & IA Super & IA & IB & IC & Category II \\
\hline Russian Maritime Register & Arc 5 & Arc 4 & Ice 3 & Ice 2 & Ice 1 \\
\hline American Shipping Bureau & IAA & IA & IB & IC & DO \\
\hline Veritas Bureau & IA SUPER & IA & IB & IC & ID \\
\hline Det Norske Veritas & ICE-1A* & ICE-1A & ICE-1B & ICE-1C & ICE-C \\
\hline Germanischer Lloyd & E4 & E3 & E2 & E1 & E \\
\hline Maritime Register of Lloyd & 1A5 & 1A & 1B & 1C & 1 D \\
\hline Nippon Kaiji Kyokai & IA Super & IA & IB & IC & ID \\
\hline Italian Maritime Register & IAS & IA & IB & IC & ID \\
\hline Thick ice thickness & - & $>50$ cm & $30-50$ cm & 15-30 cm & $10-15 \mathrm{~cm}$ \\
\hline
\end{tabular}


Due to the dynamic ice formation and ice fields, weather forecasts for more than half a century (from 1950 to 2018) were analyzed, which were processed by statistical methods and summarized in graphical, tabular and analytical forms. The nature of the interaction of broken ice with the hull of the ship, except for the drift of ice fields and ice floes, as well as their ability to create ice bars in the form of ice hummocks, depends on the age of the ice channel laid by the icebreaker [2]. An important issue is to establish the nature of extreme ice loads on the considered section of the waterway for the subsequent selection of the energy characteristics of icebreakers.

According to methodological considerations, a section of a waterway under ice conditions in non-Arctic seas can be divided into three types according to ice conditions:

1) fast ice;

2) thin ice;

3) free water.

The position of the ice edge and its distribution depends on the severity of winter and is of a complex systemic nature. So, all winters can be divided into three types:

1) severe;

2) moderate;

3) soft.

Therefore, the first statistical methods determine the sections of the route that present serious difficulties for navigation along the waterway and are characterized by the length of ice routes. Let's consider the Mariupol - Kerch route, the average distance of a sea route is 115 nautical miles. In a severe winter, the ice track in the fast ice will take $110 \pm 5$ nautical miles, to moderate - in the fast ice $22 \pm 2$ nautical miles, in the floating ice - about 82 nautical miles and in free water - only $10 \pm 4$ nautical miles. In a soft winter, the situation is different - in the fast ice $5 \pm 1$ nautical miles, in floating ice $10 \pm 5$ nautical miles and in free water - about 100 nautical miles.

Let's consider the route Kerch - Berdiansk, which averages 95 nautical miles. In severe winter, navigation in fast ice may take about $92 \pm 3$ nautical miles. In a soft winter, in floating ice, ships must move 25 nautical miles, and 70 nautical miles in free water. If the winter is soft, then the Kerch - Berdiansk highway will be completely free through the water.

Therefore, in the severe winter, the length of the Mariupol - Kerch route in the fast ice is $100 \%$, in moderate $10 \%$ in the fast ice, $60 \%$ in the floating ice and $30 \%$ in free water, and in the soft ice $-5 \%$ in the fast ice, $15 \%$ in the floating ice and $80 \%$ free water.

The ice fields to Mariupol and Berdiansk are highly variable over the months, this is due to weather conditions, and in particular with the strength and direction of the wind, air and water temperature. The greatest changes can be noted from December to January, with a shift to the south, and from February to March, with a shift of the isochron to the north.

It is also necessary to take into account the thickness of the ice, which in different areas of the Sea of Azov, depending on the type of winter, may differ significantly.

In the northern part of the Sea of Azov, the duration of the ice period takes $100 \pm 12$ days and in a soft winter the ice thickness is $0.5 \mathrm{~m}$. In a severe winter, the thickness increases to $0.8-1.0 \mathrm{~m}$. In the western part in the soft winter the thickness ice ranges from $0.1-0.3 \mathrm{~m}$, and in a severe winter from $0.6-0.8 \mathrm{~m}$. The eastern part has the same ice period, $100 \pm 15$ days, but the thickness of the ice in a soft winter is $0.1-0.3 \mathrm{~m}$, and in severe $0.6-0.8 \mathrm{~m}$. The central part has an ice period of about 90 days, and the thickness of ice in soft winters is $0.2 \mathrm{~m}$, and in severe ones $0.6 \mathrm{~m}$. The Kerch Strait has ice period of about $55 \pm 5$ days. The thickness of ice in soft winters is about $0.42 \mathrm{~m}$, as in severe.

Linear empirical dependencies with the determination of the coefficients of the equations for the direct timing of the onset of ice phenomena and characteristics of the ice cover depending on the geographical latitude of the location or the upcoming location of the ship were proposed in [12]. These equations are aimed at streamlining the work of the port during ice conditions and, in particular, for planning ice operations.

As a result of the analysis, an algorithm is developed for predicting the state of the ice cover in order to form convoys and select an icebreaker:

1. It is necessary to determine the route of the convoy, the area of navigation and the type of winter.

2. Depending on the type of winter, determine the length of the path in the ice.

3. Interpolation isochrones are established by the interpolation method. The longitude and latitude of the fast ice at the beginning and end of the route is determined.

4. The main icebreaker is selected depending on the thickness of the ice in the northern part of the location of the convoy.

5. Determine the thickness of the ice cover throughout the route, depending on the area of navigation and the type of winter.

6. For each of the ports of the Sea of Azov, depending on its location, the average statistical characteristics of the ice operation are determined.

The authors make an assessment of the efficiency of the carrying capacity of the waterways of the Sea of Azov during the ice period. When calculating, it is proposed to introduce a capacity factor (1), which will determine the possibility of increasing the port capacity, reduce the time and cost of organizing cargo delivery to/from the port.

$$
K_{c}=\frac{A_{s}}{T_{s}},
$$

where $A_{s}$ - the quantitative assessment of actually processed ships in the ice period; $T_{s}$ - the quantitative assessment of theoretically processed ships in the ice period.

The components of the ice company affect the carrying capacity of the ports of the Sea of Azov, the conditions for safe navigation, and environmental pollution. Using the seasonality factor taking into account the proposed algorithm, let's consider the possibility of ensuring continuous cargo turnover using the example of a dry cargo ship with deadweight of about 30.000 tons.

The cost of a call at the ports of Ukraine is calculated based on the tonnage of the ship. According to the new tariff rates [13], the average cost of a ship call for a dry cargo ship with a gross tonnage of 30.000 register tons is 24.000 USD. When using an icebreaker, the cost of a call at least increases by 8.000 USD and is 32.000 USD. The average number of ships that an icebreaker can carry in 1 exit, taking into account the predicted external factors, may be 10 ships, that is, the savings may be more than $90 \%$. The cost of maintaining the icebreaker is approximately 6500 USD per day, excluding fuel costs. 
By rationalizing the management of the port infrastructure, it is assumed that using the developed algorithm for predicting the state of ice cover to form convoys, the icebreaker instead of 10-15 departures for pilotage can reduce their number to $4-5$. At the same time, spending the maximum possible number of ships of approximately one tonnage, which will significantly reduce port costs and increase its profits, as well as the attractiveness of ports for foreign ship-owners.

Optimization of port infrastructure management during the ice navigation period will lead to significant savings for ship-owners (Table 3). This will positively affect the competitive position of the port and will contribute to attracting cargo flows during the entire calendar period, regardless of the presence of ice cover.

Table 3

Financial performance of the ship during the period of ice and non-ice navigation

\begin{tabular}{|l|c|c|}
\hline Financial performance & Ice period & Non-ice period \\
\hline Capacity coefficient & 0.6 & 0.9 \\
\hline The sum of costs, USD: & & \\
- fuel; & 22050 & 20009 \\
- port charges & 204189 & 174179 \\
\hline Total costs, USD & 226239 & 194188 \\
\hline Profit, USD & 87812 & 200771 \\
\hline
\end{tabular}

Reducing the cost of maintaining and operating icebreakers by reducing their access to sea also reduces port costs.

\section{SWOT analysis of research results}

Strengths. With the help of the formulated concept of the seasonality factor and ice formation forecasting, based on the developed verbal algorithm, it is possible to achieve a reduction in the cost of using an icebreaker during ice navigation. It is assumed that the decrease in the icebreaker exits can be reduced from 10-15 to 4-5. This, in turn, will significantly reduce the port costs for the maintenance of the icebreaker and increase the performance of the ports during ice navigation.

Weaknesses. This method requires testing. The analyzed data make up more than half a century. It is necessary to continue to further analyze and collect data on the ice situation and its impact on the performance of the ports. Climate change may contribute to the fact that data and algorithms will need to be reviewed under the changing situation. The use of these algorithms for other seas and ports will require an analysis of the ice situation and its influence on the performance of specific ports in a strictly allotted period.

Opportunities. Further studies of the performance of ports during ice navigation can provide an opportunity to more effectively plan the logistics of sea freight by both the port and the shipper and ship-owner. With the increase and optimization of port performance, previously undetected problems in the performance of seaports can be detected.

Threats. Testing this method can take enough time and resources for both the icebreaker and the port. Misuse, interpretation of this algorithm can lead to negative consequences for the ship, the port and the environment.
The data analyzed that should be constantly updated and take into account the general climate situation and trend.

\section{Conclusions}

1. In order to increase the efficiency of the port traffic during ice navigation, the concept of seasonality is formulated. The analysis of the severity of winter made it possible to divide it into three types, for further use in the analysis.

2. As a result of analyzing the methods for determining the main dimensions of ships for navigation on channels, fairways and maneuvering zones in tabular form, a method has been created for calculating the maximum and safe values for the main ship dimensions. This method comprehensively takes into account the basic processes in the elements of the «ship-waterway-weather-maneuvers» system to increase the capacity of waterways. It is also distinguished by the fact that it uses proven calculation methods, which, together with increasing the informativeness of the system, allow to take into account both the natural and production aspects of the transport process, and not just the draft of the ship as a factor of safe navigation. Effective and safe ice-laying will not only increase the safety of navigation during the ice period, but also increase the efficiency of ports. It is also planned to reduce the costs of ship-owners and the ports themselves at the expense of more economical and safe use of the icebreaker.

3. As a result of statistical analysis and data processing for the period from 1950 to 2018, a method has been developed in the form of a verbal algorithm. This method allows not only qualitatively, but also quantitatively establishes the types and nature of ice loads on ships along difficult sections of the sea route. At the same time, ice phenomena and severity of winter are taken into account for safe ship navigation during the winter navigation period using the example of the Sea of Azov. As a result, a significant decrease in the port turnover during the ice period is proved and ways to increase the capacity of waterways during the ice period are proposed.

\section{Acknowledgements}

The authors are grateful for the help and information provided to the administration team of the seaports of Ukraine, as well as the state enterprise Mariupol Sea Trade Port (Ukraine).

\section{References}

1. Pokazateli raboty 2019 // Administratsiya morskikh portov Ukrainy. URL: http://www.uspa.gov.ua/ru/pokazateli-raboty

2. Lobanov V. A. Modelirovanie vzaimodeystviya l'da s konstruktsiyami // Vestnik nauchno-tekhnicheskogo razvitiya. 2011. Issue 10 (50). P. 31-39.

3. Golikov V. V., Lysyy A. A. Raschet maksimal'no dopustimykh prokhodnykh kharakteristik sudna $\mathrm{v}$ portovykh vodakh // Zabezpechennya bezavariynogo plavannya suden: proceeding. Odessa: VidavInform ONMA, 2012. P. 67-69.

4. Winter navigation at the Baltic Sea: An analysis of accidents occurred during winters 2002-2003 \& 2009-2013/Valdez Banda O. A. et. al. // Safety and Reliability: Methodology and Applications. Wroclaw, 2014. P. 83-92. doi: http://doi.org/ 10.1201/b17399-14

5. Boström M., Österman C. Improving operational safety during icebreaker operations // WMU Journal of Maritime Affairs. 2016. Vol. 16, Issue 1. P. 73-88. doi: http://doi.org/10.1007/ s13437-016-0105-9 
6. Dashkevich L. V., Nemtseva L. D., Berdnikov S. V. Otsenka ledovitosti Azovskogo morya v XXI veke po sputnikovym snimkam Terra/Aqua MODIS i rezul'tatam matematicheskogo modelirovaniya // Sovremennye problemy distantsionnogo zondirovaniya zemli iz kosmosa. 2016. Vol. 13, Issue 5. P. 91-100.

7. Zamerzanie Azovskogo morya i klimat v nachale XXI veka / Matishov G. G. et. al. // Vestnik Yuzhnogo nauchnogo tsentra RAN. 2010. Vol. 6, Issue 1. P. 33-40

8. Baran J., Górecka A. Seaport efficiency and productivity based on Data Envelopment Analysis and Malmquist Productivity Index // Logistics \& Sustainable Transport. 2015. Vol. 6, Issue 1. P. 25-33. doi: http://doi.org/10.1515/jlst-2015-0008

9. Definition of Efficiency and Safety Criteria for Icebreake in Ice Management Operations / Karulin E. et. al. // Volume 8: Polar and Arctic Sciences and Technology; Petroleum Technology. 2018. doi: http://doi.org/10.1115/omae2018-77404

10. Dergausov M., Justification of the choice of an icebreaker for winter navigation in the Azov Sea // Shipbuilding and Marine Infrastructure. 2018. Issue 1 (9). P. 108-114.

11. Pravyla lodovoho provedennia suden: Nakaz Ministerstva infrastruktury Ukrainy No. 14 vid 12.03.2011. Ministerstvo yustytsi Ukrainy No. 447 (19185). 04.04.2011. 15 p
12. Zinchenko S. G., Yanchetskyi O. V. Analysis of ice conditions of winter navigation in the Azov sea for the substantiation of the icebreaker selection // Collection of Scientific Publications NUS. 2018. Issue 1-2. doi: http://doi.org/10.15589/jnn20180102

13. Pro znyzhennia stavok portovykh zboriv: Nakaz Ministerstva infrastruktury Ukrainy 27.12.2017. No. 474. URL: http://zakon. rada.gov.ua/laws/show/z0046-18

Lysyy Andrey, PhD, Associate Professor, Department of Navigation and Handling Ship, Azov Maritime Institute of National University «Odessa Maritime Academy», Mariupol, Ukraine, e-mail: anlis@ami.edu.ua, ORCID: http://orcid.org/0000-0002-5596-0856

Kotenko Vitaliy, Postgraduate Student, Department for Technical Operation of the Fleet, National University «Odessa Maritime Academy»,Ukraine, e-mail:dogyua@gmail.com, ORCID: http://orcid.org/ 0000-0002-3044-7570

Yakovtsev Stanislav, Postgraduate Student, Department for Technical Operation of the Fleet, National University «Odessa Maritime Academy»,Ukraine, e-mail: Stanislavyakovtsev@gmail.com ORCID: http://orcid.org/0000-0003-1293-1403

\section{Loria M. RESEARCH OF THE OF IDENTIFICATION ALGORITHM OF CONTROL OBJECT OF SECOND-ORDER LINKS WITH A DELAY TIME}

Об’єктом дослідження є оптимальні настроювання регулятора та показники якості перехідних процесів. Одним з найбільи проблемних місць є те, що сучасні технологічні процеси є складними об'єктами керування, при проектуванні систем автоматизації важливим стає питання ідентифікації об'єкту керування та розрахунок настроювань регулятора $і$ їх оптимізація. Оптимальні настроювання регулятора дозволять забезпечити максимально можливу в умовах даної технології якість продукції та мінімальну ï собівартість при заданому обсязі виробнищтва. Визначення оптимальних настроюваних параметрів регулятора шляхом проведення експерименту на самому об'єкті може призвести до втрати якості готової продукції, псування сировини, каталізаторів. Алгоритм розрахунку було реалізовано за допомогою програмного пакету «Maple».

В ході дослідження запропоновано і досліджено алгоритм ідентифікащії об'єктів управління з різним характером перехідних прочесів ланками другого порядку з часом запізнювання. В ході дослідження, на підставі отриманих таким чином передавальних функиій еквівалентних об'єктів, були знайдені настройки П-, ПІ- і ПІД-регуляторів (пропориійних, пропориійно-інтегральних і пропориійно-інтегральнодіферениійних регуляторів) методом трикутників, методом незагасаючих коливань (метод НіколасаЦиглера) $i$ з використанням запропонованого алгоритму. Ці настройки призначені для автоматичних систем регулювання. Проведений порівняльний аналіз показників якості перехідних процесів досліджуваних автоматичних систем регулювання при настройках, що отримані різними методами. За результатом порівняльного аналізу зроблено висновок, що знайдені параметри регулятора за запропонованим алгоритмом значно поліпшили динамічні властивості системи (перерегулювання, час регулювання, статична i динамічна погрішності). Запропоновано і досліджено алгоритм пошуку настройок регулятора з введенням обмеження на перерегулювання перехідного процесу, який показав також позитивний результат. Погрішність ідентифікації не перевищує 3 \%, що є иілком допустимо для розрахунків такого типу.

Ключові слова: ланка другого порядку, настройки регулятора, час регулювання, алгоритм ідентифікації, перехідний процес, час запізнення.

\section{Introduction}

The rising cost of raw materials on world markets causes a rapid increase in the cost of production of Ukrainian industries. Thus, at present, the share of the cost of natu- ral gas in chemical products reaches $75 \%$. So, in order for Ukrainian products to be competitive in the global market, there is an acute need for more efficient use of raw materials, energy, and the like. That is, it is necessary to carry out optimization of technological processes. 